\title{
Study Concerning Mechanical behavior for 3D Printing Parts
}

\author{
Besnea Daniel, Dana Rizescu, Ciprian Ion Rizescu, Victor Constantin, Spanu Alina, and Panait Iolanda \\ Constanta
}

\begin{abstract}
The research was developed at University POLITEHNICA of Bucharest, Faculty of Mechanical Engineering and Mechatronics. There were several challenges regarding to technological aspects. In the paper is presented the manufacturing process by adding the material which uses the raw material in the solid state between three systems to print provided with one extruder and with two extruders. Also, there were considered different fill densities. For each printer, the workpieces were printed in horizontal position and vertical position. Thus, there were designed and printed a couple of physical models used in sporting activities, in accordance with the 3D models. There are presented some remarks about the quality for the two printing systems.
\end{abstract}

Index Terms-Composite materials, fill density, hardness, mechanical behavior.

\section{INTRODUCTION}

There are many questions about mechanical behavior of printed parts. Are these parts enough resistant when different forces or moments are applied? If in printing processes a fill density is used, which is the strength of these parts? The authors decided to considered two PLA materials: a PLA with plastic aspect and a PLA with wood aspect which will be named from now on: PLA and PLA wood. At the same time there were considered two fill density ratio: $20 \%$ and $70 \%$.

It is known that Polylactic acid or polylactide (PLA) is a thermoplastic aliphatic polyester derived from renewable resources, such as corn starch (in the United States), tapioca roots, chips or starch (mostly in Asia), or sugarcane (in the rest of the world). For instance, in 2010, PLA was the second most important bioplastic of the world in regard to consumption volume [1].

PLA is used as a feedstock material in 3D printers such as Reprap and Makerbot. PLA is a biodegradable plastic with a lot of features that make it great for 3D printing. It doesn't give off fumes like ABS does, or warp nearly as much. It is also really shiny. PLA is harder than ABS, but more brittle, but that doesn't mean that it's easily breakable and it is actually super strong. And it also stays flexible for a short while as it cools, which can be handy. And it doesn't warp and crack on

Manuscript received April 1, 2018; revised April 28, 2018. This work was supported in part by University Politehnica of Bucharest, through the "Excellence Research Grants" Program, UPB - GEX. Identifier: UPB-EXCELENȚĂ-2017 Research project title, Contract number 48/25.09.2017 ME14-17-05, ID98.

Besnea Daniel, Dana Rizescu, Ciprian Ion Rizescu, Constantin Victor, Spanu Alina, Panait Iolanda Constantaare with the Politehnica University of Bucharest, Bucharest, Romania (e-mail: d_bes@yahoo.com, danarizescu@netscape.net, victor.f.constantin@gmail.com, ciprianrizescu2001@gmail.com, iolanda_pan@yahoo.com) larger objects the way ABS can. Basically, each is better for different kinds of things, and getting comfortable with PLA will give you choice and flexibility [1], [2].

\section{DESIGN AND PRINTING PARTS}

The authors used Inventor 2016 for workpiece design. To perform a print, the machine reads the design from $3 \mathrm{D}$ printable file (.stl file) and lays down successive layers of liquid, powder or sheet material to build the model from a series of cross section. These layers, which correspond to the virtual cross section from the CAD model, are joined or automatically fused to create the final shape. There were used two different materials.

The project propose the development of a technology having as result the individualized pieces, in order to fulfill at the same time functional and optional requirements requested by the users. Using three different 3D printers and two different materials (colors) we were able to compare surface quality, printing times, build supports of the workpieces. These printers are: Makerbot, Delta and our printer, developed at University POLITEHNICA of Bucharest. For each printer the workpieces were printed in horizontal and vertical positions. Using two different materials (PLA and PLA wood the surface quality is improved for the vertical printed position.

In Fig. 1 is shown the PLA part printed in horizontal position with $20 \%$ fill density ratio. In figure 2 the fill density ratio is $70 \%$. For these fill density ratios $(20 \%$ and $70 \%)$ there were considered four center thickness: 2, 4, 6 and $8 \mathrm{~mm}$. There were printed parts using PLA and parts using PLA wood for all mentioned thicknesses. At the same time there were considered the printing plane: horizontal and vertical with respect to the base $3 \mathrm{D}$ printer plane (axis $\mathrm{OZ}$ parallel with base plane and perpendicular to the base plane).

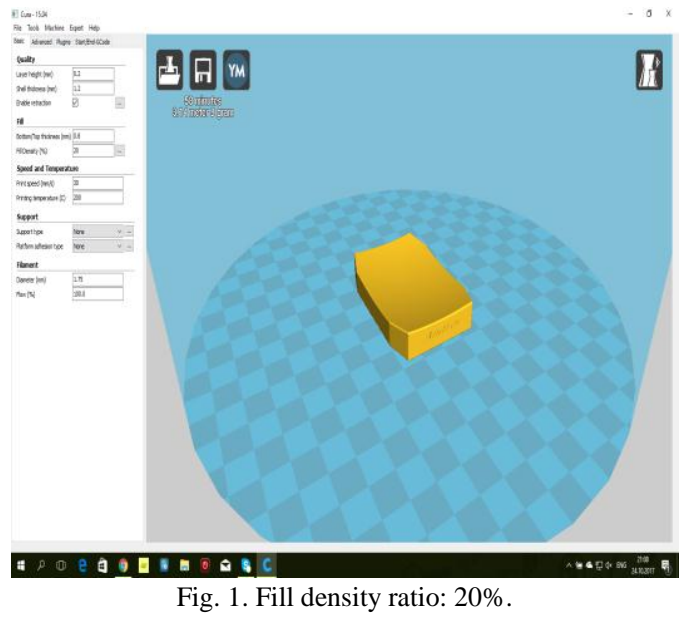




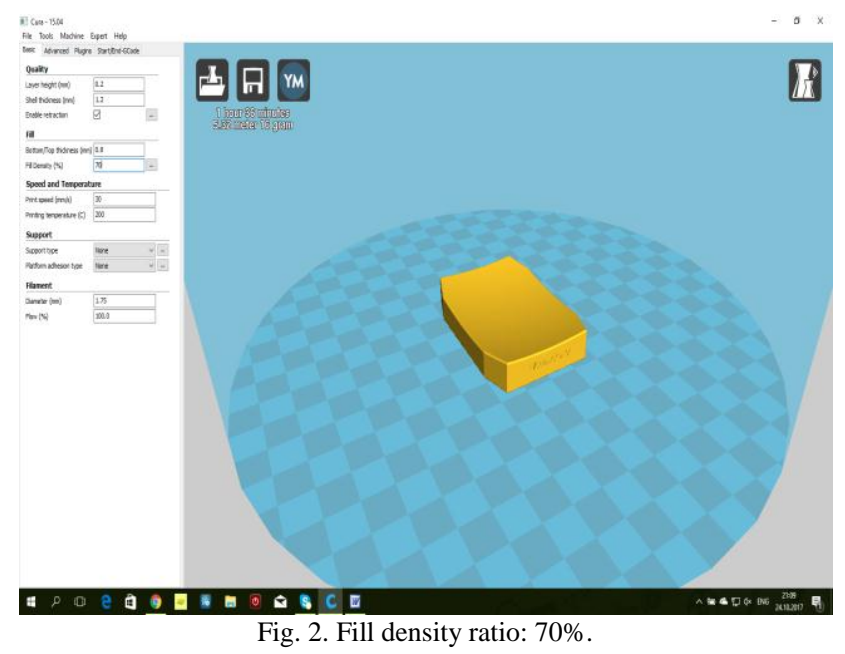

In Table I there are shown all considered parts characteristics [3], [4].

\begin{tabular}{|c|c|c|c|c|c|}
\hline \multirow[t]{2}{*}{ No. } & \multicolumn{5}{|c|}{ Center Thickness b } \\
\hline & $\begin{array}{c}2 \\
{[\mathrm{~mm}]}\end{array}$ & $\begin{array}{c}4 \\
{[\mathrm{~mm}]}\end{array}$ & $\begin{array}{c}6 \\
{[\mathrm{~mm}]}\end{array}$ & $\begin{array}{c}8 \\
{[\mathrm{~mm}]}\end{array}$ & $\begin{array}{c}\text { Fill } \\
\text { Density } \\
{[\%]}\end{array}$ \\
\hline 1 - PLA & $\mathrm{H} / \mathrm{V}$ & $\mathrm{H} / \mathrm{V}$ & $\mathrm{H} / \mathrm{V}$ & $\mathrm{H} / \mathrm{V}$ & $20 / 70$ \\
\hline 2 - PLA Wood & $\mathrm{H} / \mathrm{V}$ & $\mathrm{H} / \mathrm{V}$ & $\mathrm{H} / \mathrm{V}$ & $\mathrm{H} / \mathrm{V}$ & $20 / 70$ \\
\hline
\end{tabular}

In Fig. 3 is presented the design of printed part, developed in Inventor 2016.

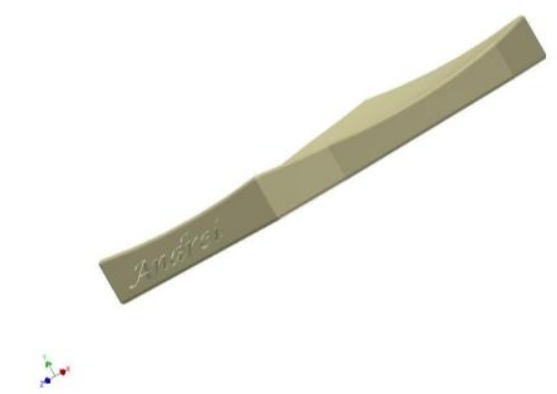

Fig. 3. The design printed part - Inventor 2016.

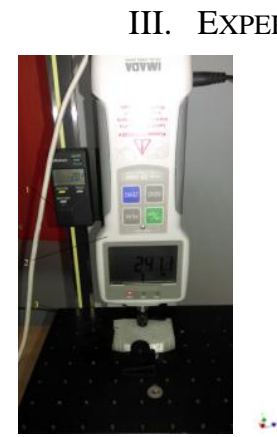

a.

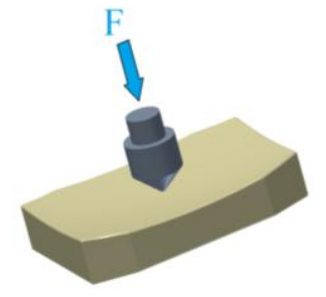

Fig. 4. a. Hans-Schmidt vertical test stand; b. Simulation of penetration with testing edge

In Fig. 4, a is presented the experimental setup based on test stand, HV $500 \mathrm{~N}$, which mainly consists of: 1- distance measuring system, 2 - Imada force transducer, 3 - printed part. Maximum testing force is $500 \mathrm{~N}$. The Imada transducer is connected to PC for record the penetration force and time. In figure $4 \mathrm{~b}$ is a simulation of penetration with testing edge. The testing edge is of a conical shape, with $90^{\circ}$ edge angle. The penetration depth is measured with distance measuring system shown in Fig. 4a. We have to underline that the maximum force allowed by Imada transducer is $500 \mathrm{~N}$.

\section{EXPERIMENTAL RESULTS}

In Fig. 5 there are presented PLA parts for fill density 20\%, printed in vertical position. In figure 6 there are shown PLA parts printed in horizontal position for fill density $20 \%$, in the left side and PLA parts with fill density $70 \%$, in the right side.

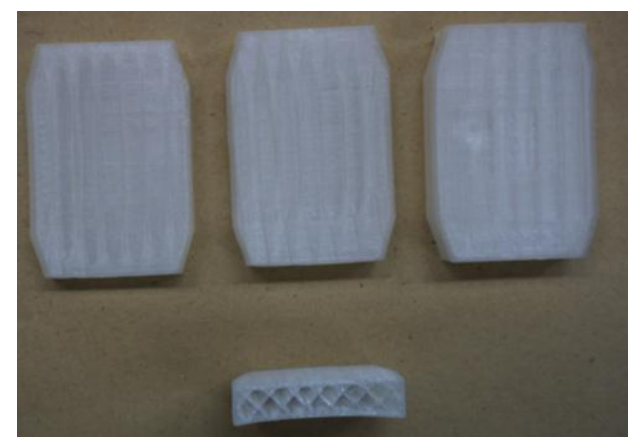

Fig. 5. PLA vertical printed with fill density $20 \%, b=4,6,8 \mathrm{~mm}$.

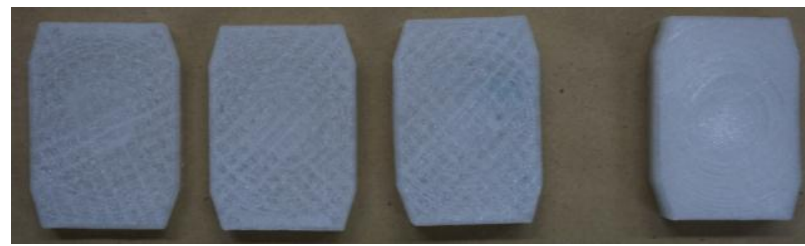

Fig. 6. PLA - horizontal printed with fill density $20 \%$, $70 \%$ (left) $\mathrm{b}=4,6,8 \mathrm{~mm}$.

In Fig. 7 the parts are printed from PLA wood material, in vertical position, with fill density $20 \%$.

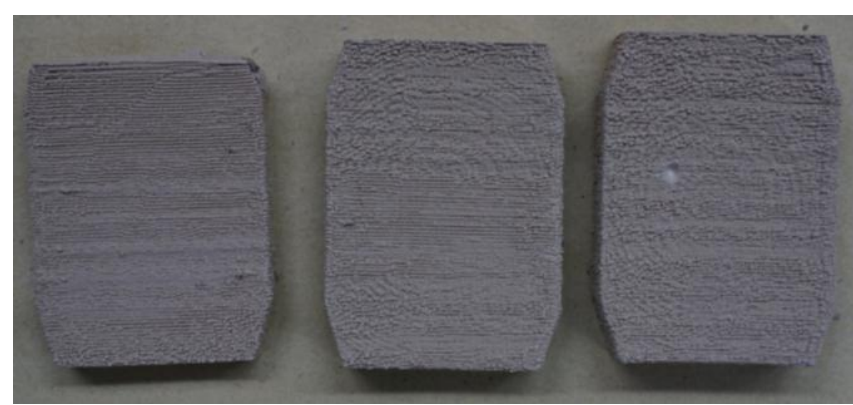

Fig. 7. PLA wood - vertical printed with fill density $20 \%, b=4,6,8 \mathrm{~mm}$.

In Fig. 8 the parts are printed from PLA wood material, in horizontal position, with fill density $20 \%$.

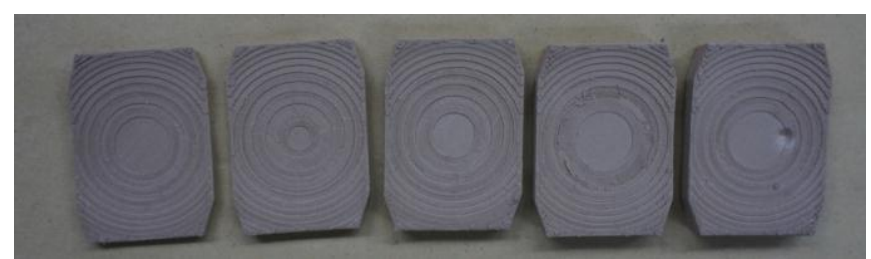

Fig. 8. PLA wood horizontal printed with density fill $20 \% \mathrm{~b}=2,4,6,8 \mathrm{~mm}$

In Fig. 9 there is a comparison between two situations: in Fig. 9, a there are two parts vertical printed from PLA with density fill: $20 \%$ and $70 \%$; in figure 9 , b there are horizontal printed parts from PLA wood with fill density $20 \%$ and $70 \%$. 

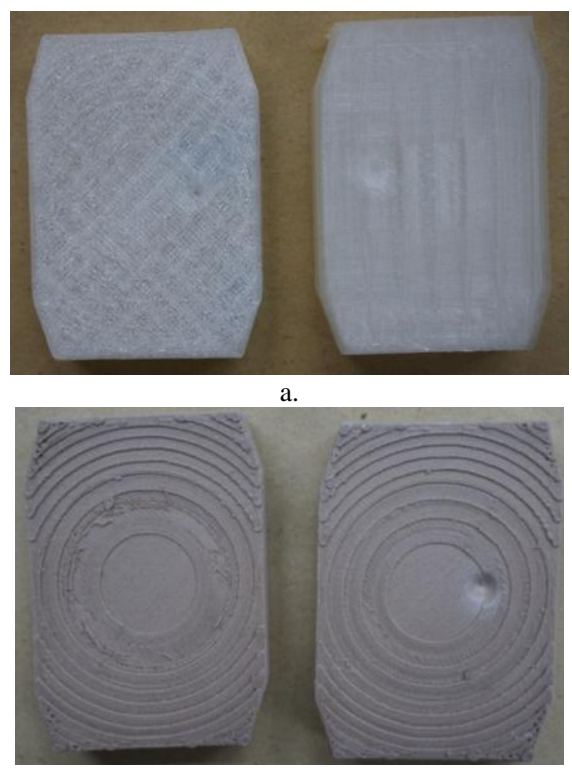

b.

Fig. 9. a. Vertical printed PLA part $\mathrm{b}=8 \mathrm{~mm}, 20 \%, 70 \%$; . Horizontal printed PLA wood part $\mathrm{b}=8 \mathrm{~mm}, 20 \%, 70 \%$.

The experimental results were plotted in Matlab environment [5] in figures $10,11,12,13$. The notation in figures below are:

- Fpv2 force PLA, vertical printing, thickness $b=2 \mathrm{~mm}$;

- Fph2 force PLA, horizontal printing, thickness $b=2 \mathrm{~mm}$;

- Fwv2 force PLA wood, vertical printing, thickness $b=2$ $\mathrm{mm}$;

- Fwh2 force PLA wood, horizontal printing, thickness b $=2 \mathrm{~mm}$;

- Fpph force PLA, horizontal printing, fill density $70 \%$.

It is very important to underline that the penetration depths depend on maximum actuating force for Imada transducer, which is $500 \mathrm{~N}$. The main criteria for this penetrations is maximum allowed force and also the thickness of the parts. For instance, in figure 10 PLA wood - printed in vertical position and $2 \mathrm{~mm}$ thickness, Fwv2, the maximum penetration depth was $1.47 \mathrm{~mm}$ which corresponds to penetration force of $216 \mathrm{~N}$. In figure 10 there are the results for PLA wood printed parts in vertical and horizontal positions and fill density $20 \%$. In Fig. 11 there are the results for PLA printed parts in vertical and horizontal positions and fill density 20\%. In Fig. 12 there are the results for PLA and PLA wood printed parts in vertical and horizontal positions for density fill $20 \%$ and for density fill $70 \%$, centre thickness $b=8 \mathrm{~mm}$. In figure 13 there is presented the relaxation process for PLA and PLA wood parts for vertical printing position and fill density ratio $70 \%$, the thickness of both parts is $b=8 \mathrm{~mm}$. One can observe that PLA wood part reached the maximum force, $500 \mathrm{~N}$, after $70 \mathrm{~s}$ and instead the PLA part reached the maximum force, $430 \mathrm{~N}$, after 80 s. Also, when penetration force for PLA wood material reached $500 \mathrm{~N}$ the depth was $2.2 \mathrm{~mm}$. For PLA part the penetration force reached $430 \mathrm{~N}$ but the depth was $3.2 \mathrm{~mm}$. The PLA wood has a higher hardness than PLA material. The parts with fill density ratio $20 \%$ have a higher hardness than parts with fill density ratio $70 \%$ for the same material.

These experimental tests were inspired from determining the hardness of materials, especially from determination of Rockwell hardness for steel. The authors will test in the future other materials in order to elaborate a general mathematical model for determining PLA hardness.
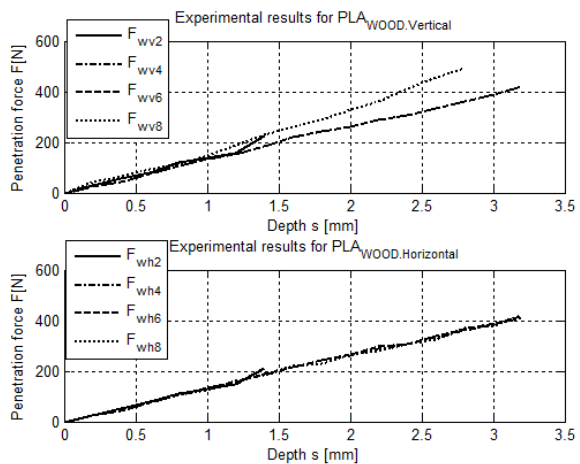

Fig. 10. The results for PLA wood printed in vertical and horizontal positions.
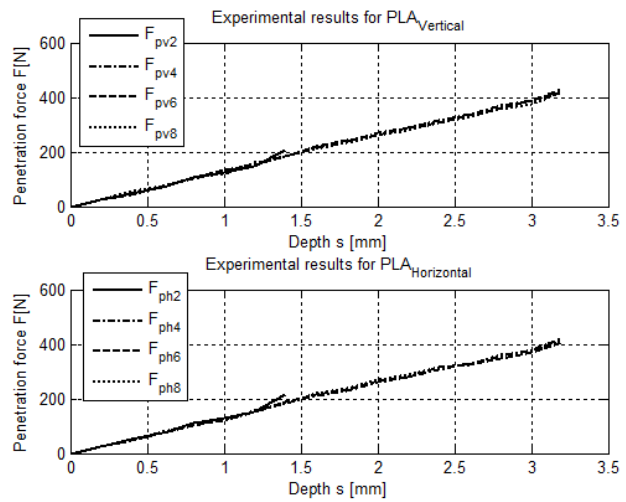

Fig. 11. The results for PLA printed in vertical and horizontal positions.

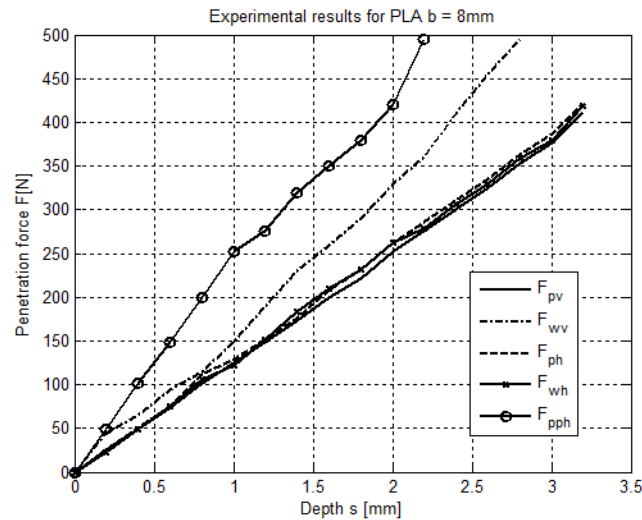

Fig. 12. The results for PLA and PLA wood printed in vertical and horizontal positions for density fill $20 \%$ and for density fill $70 \%$, centre thickness $b=8$ $\mathrm{mm}$.

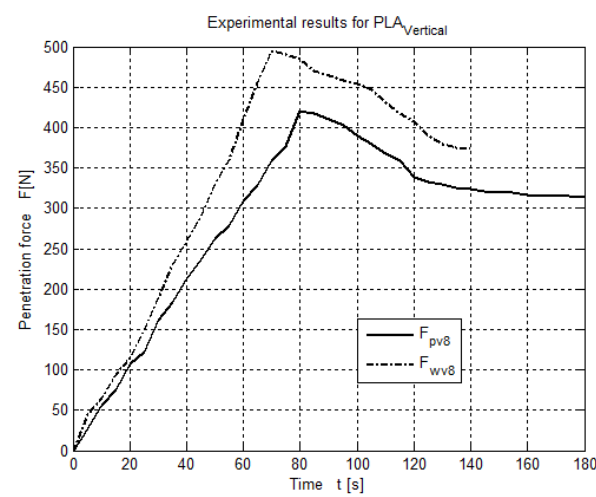

Fig. 13. The relaxation process for PLA and PLA wood for vertical printing position and density fill ratio $70 \%$. 
Maximum penetration forces are presented in Table II [6]

TABLE II: MAXIMUM PENETRATION FORCES

\begin{tabular}{lccccc}
\hline \hline & \multicolumn{4}{c}{ Center Thickness, b } \\
\cline { 2 - 6 } & $2[\mathrm{~mm}]$ & $4[\mathrm{~mm}]$ & $\begin{array}{c}6 \\
{[\mathrm{~mm}]}\end{array}$ & $\begin{array}{c}8 \\
{[\mathrm{~mm}]}\end{array}$ & $\begin{array}{c}\text { Fill Density } \\
{[\%]}\end{array}$ \\
\hline 1 - PLA & $390 \mathrm{~N}$ & $405 \mathrm{~N}$ & $410 \mathrm{~N}$ & $425 \mathrm{~N}$ & 20 \\
2-PLA Wood & $395 \mathrm{~N}$ & $405 \mathrm{~N}$ & $425 \mathrm{~N}$ & $495^{*} \mathrm{~N}$ & 20 \\
1 - PLA & $425 \mathrm{~N}$ & $435 \mathrm{~N}$ & $455 \mathrm{~N}$ & $495^{*} \mathrm{~N}$ & 70 \\
2-PLA Wood & $435 \mathrm{~N}$ & $440 \mathrm{~N}$ & $460 \mathrm{~N}$ & $495^{*} \mathrm{~N}$ & 70 \\
\hline \hline
\end{tabular}

* Limited by $500 \mathrm{~N}$ force transducer.

\section{CONCLUSIONS}

There were tested two materials: PLA and PLA wood. The parts were designed with different centre thicknesses and were printed both in horizontal and vertical positions with respect to the base plane of $3 \mathrm{D}$ printers. There were tested two fill density ratios: $20 \%$ and $70 \%$. The PLA wood has a higher hardness than PLA material, for both printing positions: vertical and horizontal. The parts with fill density ratio $20 \%$ have a higher hardness than parts with fill density ratio $70 \%$ for the same material. The authors will test in the future other materials in order to set up a general mathematical model for determining PLA, ABS hardness.

\section{ACKNOWLEDGMENT}

This work has been funded by University POLITEHNICA of Bucharest, through the "Excellence Research Grants", Program UPB-GEX 2017. Identify: UPB-GEX2017, Grant no. 48/25.09.2017, ME 14-17-05, ID 98.

\section{REFERENCES}

[1] P. Berce, N. Balc, C. Caizar, R. Pacurar, A. S. Radu, S. Bratean, and I Fodorean, Tehnologii de Fabricaţie Prin Adăugare de Material si Aplicaţiile Lor, Editura Academiei Romane, Bucureşti, 2014.

[2] P. Berce, N. Balc, S. Ancau, H. Comsa, and H. C. Chezan, Fabricarea rapIda a Prototipurilor, Editura Tehnica, Bucureşti, 2000.

[3] C. Stancescu, Modelarea parametrica si adaptiva cu Inventor, Editura FAST, Bucureşti, vol. I and II, 2000.

[4] Support. [Online]. https:/eu makerbot.com/fileadmin Bot_R_PLA_and_ABS_Strength_Data.pdf

[5] C. I. Rizescu, Software Pentru Sisteme Mecatronice, Partea I, Editura Printech, Bucureşti, 2013.

[6] Vertical_Manual.

[Online]. Available:http://www.hans-schmidt.com/EN/products/force_gauge_a nd_test_stands/test_stands/vertical_manual_test_stands/model_hv-50 0 n

Daniel Besnea was born in Buzau, Romania, on July 19, 1967. He graduated the "Politechnica" University of Bucharest, Faculty of Fine Mechanics and Doctoral School of Faculty of Mechanical Engineering and Mechatronics, receiving PhD engineer. Eng. degree.

He published: Materiale si tehnologii de fabricatie, Editor Printech Bucuresti, 2017, Tehnologii mecatronice si aplicatiile lor Editor Printech Bucuresti, 2017, Tehnologii de fabricatie asistate de calculator, Editor Printech, Bucharest, 2008; Utilizarea aplicatiilor de tip CAD, Editor CD Press, Bucuresti, 2007; Metrologie si control dimensional, Editura Academiei Oamenilor de Stiinta din Romania, Bucharest, 2011.

Dr. Daniel Besnea is member of SROMECA (Romanian Society of Mechatronics) and member of The Romanian Robotics Society.
Dana Rizescu was born in Bucharest, Romania, on 6th July 1965. Now, she is assist. professor at University Politehnica of Bucharest. She is Ph.D in the field of mechanical engineering, 1997, Bucharest, Romania, University POLITEHNICA of Bucharest.

She published: Complemente de mecatronica. Editura Printech, Bucuresti, 2000, Aplicatii la mecanisme de mecanica fina, Editura Printech, Bucuresti, 2015.

Member of professional asociations: Romanian Association for Precision Engineering and Optics, (AMFOR), Romanian Association for Machine Theory and Mechanisms, (ARoTMM), Romanian Society for Mechatronics, (SROMECA), Romanian Society for Robotics (SRR).

Ciprian Rizescu was born in Bucharest, Romania, on 2nd October 1963. Now, he is assoc. professor at University POLITEHNICA of Bucharest. He is $\mathrm{PhD}$ in the field of mechanical engineering, 1997, Bucharest, Romania, University Politehnica of Bucharest. He published: Elemente de mecatronica. Editura Printech, Bucuresti, 2000, Elemente si mecanisme de mecanica fina - Partea I, 2013, Editura Printech, Bucuresti, 2013. Software pentru sisteme mecatronice- Partea I , 2013, Editura Printech, București, 2013, Aplicatii la mecanisme de mecanica fina, Editura Printech, Bucuresti, 2015.

Member of professional asociations: Romanian Association for Precision Engineering and Optics, (AMFOR),Romanian Association for Machine Theory and Mechanisms, (ARoTMM), Romanian Society for Mechatronics, (SROMECA),Romanian Society for Robotics, (SRR), Association of Energy Auditors for Buildings in Romania (AAECR).

Victor Constantin, was born in Bucharest, Romania, on June 17, 1980. He graduated the "Politechnica" University of Bucharest, Faculty of Fine Mechanics and Doctoral School of Faculty of Mechanical Engineering and Mechatronics, receiving $\mathrm{PhD}$ engineer. Eng. degree. He published Utilizarea aplicatiilor de tip CAD, Editor CD Press, Bucharest, 2007. Dr. Victor Constantin is member of SROMECA (Romanian Society of Mechatronics) and member of The Romanian Robotics Society.

Spanu Alina was born in Bucharest, Romania, on November 29, 1958. She graduated the "Politechnica" University of Bucharest, Faculty of Fine Mechanics and Doctoral School of Faculty of Mechanical Engineering and Mechatronics, receiving PhD engineer. Eng. degree.

She published:Grafica 3D asistata de calculator, Editor Printech, Bucharest, 2016; Programarea calculatoarelor - notiuni de baza si aplicatii, Editor Printech, Bucharest, 2015

Dr. Spanu Alina is member of SROMECA (Romanian Society of Mechatronics) and member of The Romanian Robotics Society/

Iolanda Constanta Panait was born in Calarasi, Romania, on August 17, 1972. She graduated the "Politechnica" University of Bucharest, Faculty of Fine Mechanics.

Some relevant publications: The Results of Superposition of Different Actions Upon the Mechanical Structures and Living Bodies (VV Jinescu, Nicoleta Teodorescu, George Jinescu), Revista de Chimie, 67, nr. 12, 2016 , p. 2607-2613, Constructive Optimisation of the Propeller Type Mixing Devices Using the Virtual and Rapid Prototyping (Daniel Besnea, Alina Spanu, Iuliana Marlena Prodea, Gheorghita Tomescu), Revista de Chimie, 68, nr. 3, 2017, p. 453-458.

Collaborator AGIR (Romanian General Association of Engineers). 